\title{
視覚的探索中の背景文字処理と眼球運動
}

\author{
関西学院大学文学部 \\ 大門若子 ${ }^{1 ｝ \text { 宮田 洋 八木昭宏 }$
}

\section{The processing of background letters and eye movements in visual search}

\author{
DAIMON, Wakako, MiYATA, Yo, \& YAGI, Akihiro
}

Department of Psychology, Kwansei Gakuin University, Uegahara, Nishinomiya, Hyogo 662, Japan

\begin{abstract}
The purpose of the experiment was to examine the effect of the background letters of the Japanese Kana-list which 10 students searched under three conditions on visual processing. One kind of background letters was physically similar to the target (PS condition), or was the nominally identical with the target (NI condition). In the control(C) conditon, neither of these letters was involved. The searching time through a list was longer in NI than in $\mathrm{C}$ and was longer in PS than in NI condition. The results suggested that the stimulus was coded not only at the physical level but at the nominal level. The fixation time was prolonged in PS and NI than in C. The number of saccades increased in PS and NI than in C, and it showed the tendency to increase in PS than in NI. It was suggested that the two factors affected the processing of background : One was the ability of capturing a letter by peripheral vision. The other was the degree of difficulty to decide whether the letter was the target or not.
\end{abstract}

Key words : visual search, fixation durations, number of saccades, letter identification, target detection.

\footnotetext{
1）本研究をまとめるにあたり適切なご助言ご協力を賜りました関西学院大学大学院片山順一氏に深く感謝致し ます。
}

1988.6 .22 受稿

1988.8 .8 受理 


\section{生理心理 6 巻1号 1988}

序

視覚的探索 (visual search) 事態に扔いて, 探索 者は, あらかじめ決められた対象（標的）を背景 の中から捜し出すことが必要である。このとき標 的か非標的かの選択はどの様な要因によって影響 を受けるのであろらか。文字列を用いた文字探索 課題では, 背景文字と標的文字との間の物理的類 似性あるいは音韻的類似性が，課題遂行に影響す ることが知られている. Neisser(1963)は，丸みを 帯びた文字 (C, Q, G 等) で構成される文字列中か ら丸みを帯びた文字 (O) を捜す場合と，角張っ た文字（Z）を捜す場合との標的検出時間を比較 した。 その結果，1列めたりの探索時間は，角 張った文字を捜す方が短くなることが明らかに なった。この結果は, 標的文字一背景文字間の物 理的な弁別可能性が課題遂行にとって重要である ことを示唆している。

同様に, Henderson (1973)は, 標的 (C) と同 じ形の文字（c）が背景文字の一つとして含まれ る場合, 課題遂行が妨害されることを示した。さ らに興味深いことには，この実験で, 標的 (A) と形は異なるが同じ音の文字（a）が背景文字の 一つとして含まれる場合にも課題遂行が妨害され ることが明らかになった。この結果は, 探索中に 背景文字の物理的特徵のみならず音韻的特徵もま た分析されていることを示している.

Henderson (1973) の実験に招いて, 音韻のみ同 一の条件 $(\mathrm{A}-\mathrm{a})$ と, 形態, 音韻とも同一の条 件 $(\mathrm{C}-\mathrm{c})$ とを比較すると, 音韻のみ同一条件 の方が, 課題遂行の妨害量が少なかった。これ は, 妨害を生じる要因となっている処理内容が両 条件間で異なっている可能性をらかがわせる。文 字の物理的特徽は刺激の特徵分析によって処理さ れるのに対し，音韻的特徴は文字の同定を含むよ り高次な分析によって処理される. 従って, 背景 文字の物理的特徵と音韻的特徵は, ともに標的検 出時間に影響を与えるが, 各々の特徵に対する処 理内容には差異があると考えられる。このよらな
処理内容の違いを検討するには，背景文字に対す る処理を直接的に評価できる指標を用いることが 望ましい。

視覚的探索場面に扔いて, 眼球は, 周辺視で捕 らえたお括まかな形態的特徵に基づいてサッケイ ドを起こし，対象を中心視内に捕らえるといら運 動を繰り返している. Rayner and Pollatsek (1981) は，この中心視内で捕らえた対象に対する 停留の持続時間 ( fixation duration) は, その対象 の処理時間に対応すると主張している.

反応時間を指標とした研究に执いてはリストを 探索する全体の時間が測定される。そのため個々 の刺激に対する処理の分析をするのは困難であ る.しかし，眼球運動を測定することにより， 個々の刺激に対する継時的な処理を扱らことがで さる，さらに，反応がない刺激に対する処理をも 扱光る可能性がある.Printz(1986)は，文字探索 中の眼球運動を記録した一連の実験 (Printz \& Kehrer, 1982 ; Printz \& Nattkemper, 1986)を通し て, 感覚特徵処理と意味同定処理とい52つのレ ベルでの処理が同時に生じている可能性を示唆し ている. Printz and Nattkemper (1986)は, 被験 者に文字列探索を行わせると共に数字をカウント するといら二次課題を課した。 その結果, これら 2 レベルのらち意味同定処理レベルのみが 2 次課 題によって妨害されることを見いだした。この実 験で，彼らは，意味同定処理の測度として列あた りの探索速度を,また，感覚特徵処理の測度とし て垂直検出距離を用いている。垂直検出距離と は，標的のある位置と，標的を検出できた時に実 際に見ていた列との差である。この測度は, 周辺 視能力に依存するといら点で特徵処理を反映する ものと考光ることができるが，標的が存在しない 場合には用いることができないという久点があ る.

本実験では，日本語かな文字を用いた文字探索 事態に拈いて, 標的文字の検出が背景文字の物理 的特徵及び音韻的特徵によって妨害を受けるか否 
かについて検討した. 更に, 探索中の眼球運動を 測定することにより，物理的妨害文字を含む探索 と音韻的妨害文字を含む探索の間で，背景文字に 対する処理内容の違いを明らかにすることを試み た.リスト探索に要する探索時間を測定すると共 に, 眼球のサッケイド回数及び停留時間を測定し た。

\section{方法}

被験者被験者は, 男子 5 名女子 5 名の大学 生であった。このうち裸眼者は 8 名, 眼鏡着用者 は 2 名であったが, 視力及び矯正視力はすべて正 常であり，実験条件下で課題を遂行することに支 障はなかった。

刺激 日本語片仮名及び平仮名からなる文字 リストが, 被験者の前方 $50 \mathrm{~cm} に$ 置かれた CRT ディスプレイ黒色背景上に白色文字で提示され た。この文字リストは, 縦 9 文字×横19文字の計 171文字を等間隔に配列したもので (Fig. 1 参照)， 1 文字の大きさは縦 $1.0^{\circ} \times$ 横 $0.6^{\circ}$, リスト全体が 占める視角は $14^{\circ} \times 24^{\circ}$ であった。刺激はすべて， 富士通製 FM-7 コンピュータによって制御され た。

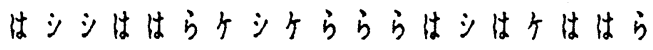

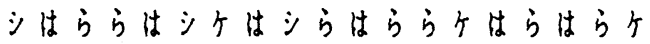

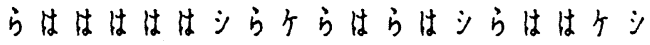

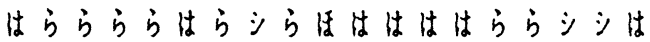

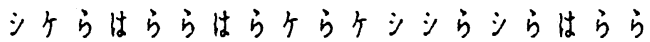

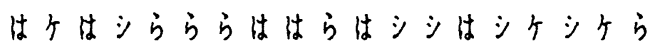

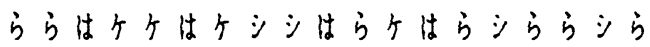

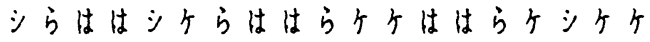

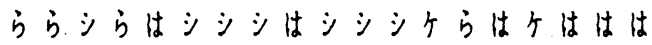

Fig. 1 An example of the search list. (Physical Similality Condition)

課題及び条件被験者の課題は, あらかじめ 指示された標的文字をりスト中から捜し，見つけ るたびに，利き手によるボタン押し反応を行らこ とであった。探索にあたっては，横書き文章を読 む時のように左から右方向に上行から順番に見て
いくことを指示した．標的文字は，1リストに 1 つとは限らないため, 必ずリストの最後まで見る ように指示し，終了時点で非利き手によるボタン 押し反応を課した。

標的文字と背景文字（リスト中に含まれる標的 文字以外の文字）との関係から，コントロール条 件, 形態類似条件, 音韻同一条件の 3 条件が設定 された。標的文字は，3 条件とも共通の文字

（ほ）であった、コントロール条件は，4 種類の 背景文字（シ・ケ・す・ら）でリストが構成され た。形態類似条件では、コントロール条件の背景 文字のうちの 1 文字を標的文字（ほ）と形態的に 類似した文字（は）に変更した。音韻同一条件で は,コントロール条件の背景文字のらち 1 文字を 標的文字（ほ）と同じ音の文字（ホ）に変更し た.ここで, 形態類似条件に括ける形態類似文字 及び音韻同一条件に拈ける音韻同一文字は，探索 を妨害する可能性を持つことから特に妨害文字と 呼んだ. Table 1に示す通り，3 条件とも背景文字 として用いた文字は 4 文字であり，1 リスト中に 含まれる各文字の個数が等頻度になるようランダ ムに配置された。

Table 1 Target and background letters for the search lists

\begin{tabular}{lcl} 
Condition & Target & Backgrounds \\
\hline Control & ほ & シ・ケ・ら・す \\
Physical Similarity & ほ & シ・ケ・ら・は \\
Nominal Identity & ほ & ホ・ケ・ら・す \\
\hline
\end{tabular}

Note : Confusable background letter is underlined.

手続き被験者は, 電極装着後, 適度な明る さの保たれた遮音室に入り, ヘッドレストによっ て頭部を固定した。課題説明とキャリブレーショ ンを行った後, 練習試行にはいった，標的文字を $2 \mathrm{~s}$ 間提示した後, 画面中央に凝視点を $5 \mathrm{~s}$ 間提示 した。凝視点消失から $6 \mathrm{~s}$ の後, リストが提示さ れた. 被験者の終了反応に応じて, リストは消 光, $5 \mathrm{~s}$ の間隔を和いて, 次試行の凝視点が提示 
された． 6 試行を続けて行い1ブロックとした 練習試行として1ブロック行った後, 本試行を, 休憩をはさみながら 6 ブロック，計 36 試行行っ た.このうち 1 条件は 12 試行ずつであり, ブロッ ク内でランダム順に行った. 1 リスト内には 1 個，2個あるいは 0 個の標的文字が含まれて招 り, 各々の場合の比率は, 1/3ずつであった。

記録 眼球運動は, EOG 法により記録され た. 右眼外側部及び左眼外側部より水平方向, 右 眼眉上及び右眼眼下から垂直方向を $\mathrm{Ag}-\mathrm{AgCl}$ 電 極により導出した。信号は高域遮断 $100 \mathrm{~Hz}$ で直流 増幅された後, TEAC製PS-9200コンピュータに よって $10 \mathrm{~ms}$ のサンプリングタイムで $\mathrm{A}-\mathrm{D}$ 変換 され，ハードディスク内に貯蔵された。

結果の処理標的を含まない試行のみを分析 の対象とした。この理由は, 本実験のねらいは背 景に対する眼球運動を検討することにあり，標的 が視野内に入ったときの眼球運動は問題としてい ないためである。従って, 分析の対象となった試 行数は被験者当り各条件 4 試行ずつであった.

実験終了後, 水平方向眼球運動を基にして, 1 リストの探索に要したサッケイド回数及び 1 回当 りの停留時間を測定した。このとき，瞬目が多い 試行あるいは，眠気等による眼球の動摇によって サッケイドの測定が困難な試行については，分析 から除外した。サッイドの検出基準は，一定方 向に $1^{\circ}$ 以上の変化がみられ, $50 \mathrm{~ms}$ 以上の停留が それに続くものとした。 また，リスト提示から探 索終了反応までの時間を測定し, 探索所要時間と した.

\section{結 果}

\section{1. 探索所要時間}

1 リストの探索に要した時間の平均を Fig. 2 に 示した。形態的あるいは音韻的妨害文字が背景文 字中に含まれることによって，探索時間はコント ロール条件よりも長くなった。ささらに形態類似条 件と音韻同一条件とを比較すると, 形態類似条件
の方が, 探索所要時間が延長した. 分散分析の結 果, 条件による主効果が認められた（F (2, $18)=33.48, \mathrm{p}<.01)$. さらに, テューキー法によ り各条件間の平均值の差を検定したところ, コン トロール条件 - 形態類似条件間 $(\mathrm{p}<.01)$, コント ロール条件一音韻同一条件間 $(\mathrm{p}<.01)$, 及び形態 類似条件一音韻同一条件間 $(\mathrm{p}<.05)$ に有意な差が 認められた。

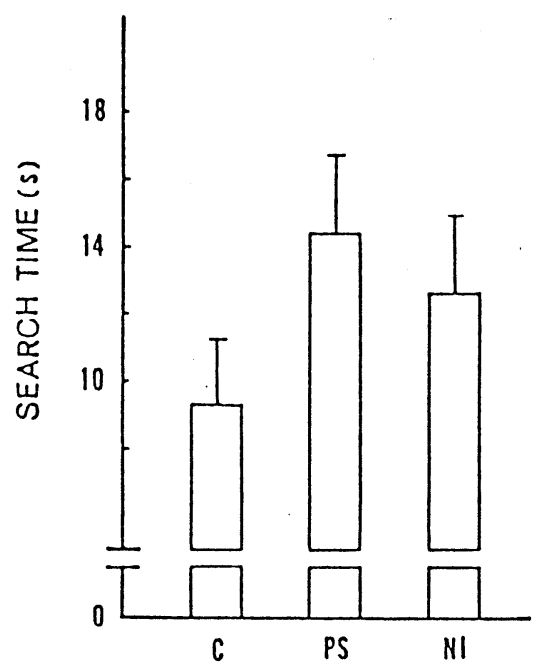

Fig. 2 Mean time required for searching through a list in each condition. C : Control, PS : Physical Similarity, NI : Nominal Identity

\section{2. 停留時間}

停留 1 回当りの持続時間を平均し, Fig. 3 に示 した. 分散分析の結果, 条件による主効果が認め られた $(\mathrm{F}(2,18)=6.50, \mathrm{p}<.01)$. さらに条件間 の比較を行ったところ, 形態類似条件の停留時間 はコントロール条件よりも有意に長くなっており $(\mathrm{p}<.01)$, 音韻同一条件の停留時間もまた, コン トロール条件よりも有意に長くなっていた $(\mathrm{p}<.05)$. 形態類似条件之音韻同一条件の間に有 意な差はなかった。

3. サッケイド回数

1 リストの探索中に生じたサッケイド回数の平 均を Fig. 4 に示した. 行替えのための右端から左 端へのサッケイドは, 全条件共通であるため, こ 


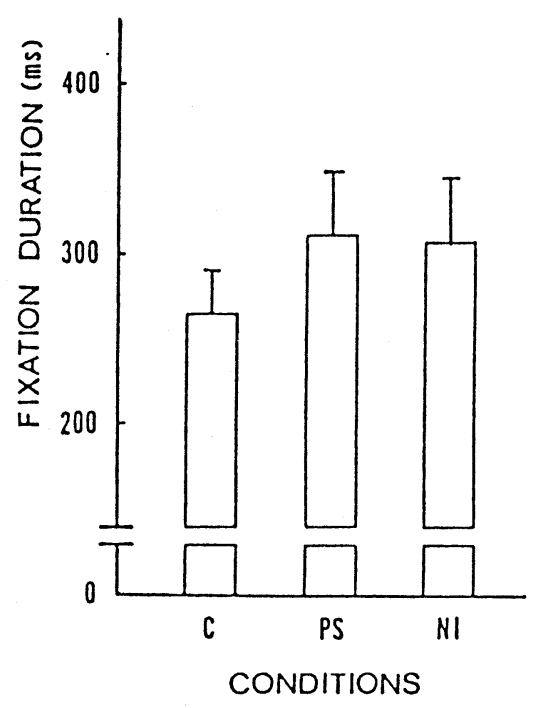

Fig. 3 Mean fixation duration.

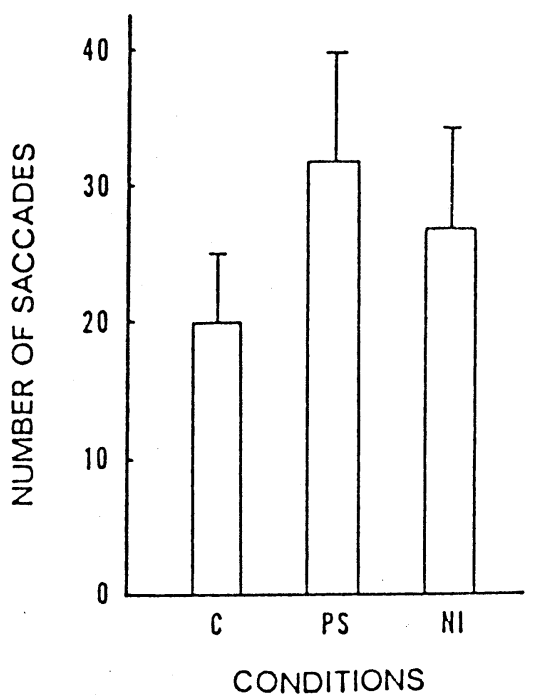

Fig. 4 Mean number of saccades for a list.

こには算入していない。

分散分析の結果, 条件による主効果が認められ た $(\mathrm{F}(2,18)=14.88, \mathrm{p}<.01)$ ．さらに, 形態類似 条件では, コントロール条件よりも回数の有意な 増加が認められ $(\mathrm{p}<.01)$, 音韻同一条件でも, コ ントロール条件よりも有意な増加が認められた $(\mathrm{p}<.05)$ ．また，形態類似条件と音韻同一条件の 間では, 形態類似条件の方が回数が増加している ようであったが，統計的には有意な差は認められ
なかった。

4. 従属変数間の相関

各試行における探索所要時間は, サッケイドの 回数之停留時間によって決定されると考えられ る. 本課題に执いて, 各条件での探索所要時間は サッケイド回数と停留時間のどちらと関連がある かを調べるために，条件毎に，探索所要時間一 サッケイド回数間, 及び探索所要時間 - 平均停留 時間間の相関を調べた。被験者 10 名について 1 試 行毎に探索所要時間, 1 試行内での平均停留時 間，サッケイド回数をプロットした（Fig. 5, Fig. $6)$.

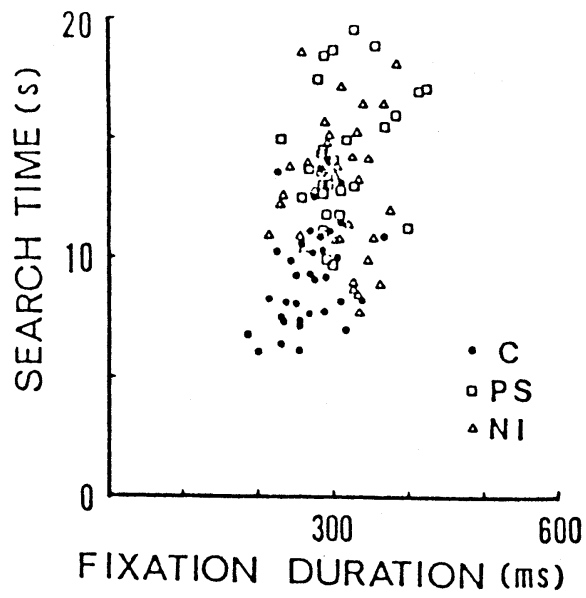

Fig. 5 Correlation between fixation duration and search time.

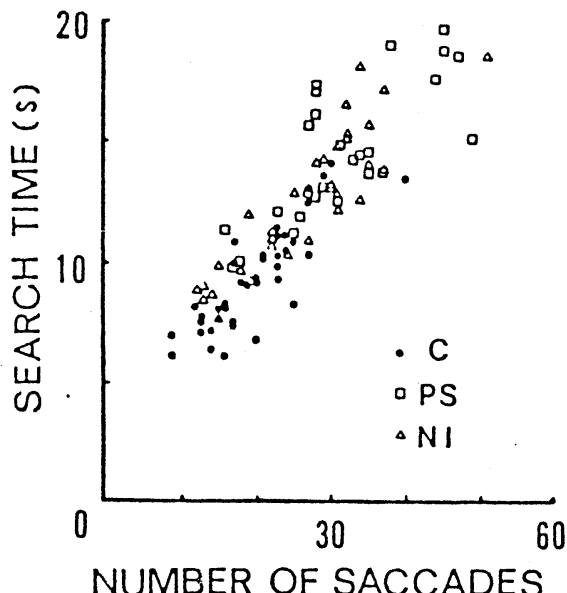

Fig. 6 Correlation between number of saccades and search time. 
探索所要時間 - 停留時間間 (Fig. 5)では, 3 条 件のいずれにおいても相関は認められなかったの に対し, 探索所要時間ーサッケイド回数間 (Fig. 6 ) では, 3 条件とも高い正の相関が認められた (コントロール条件 : $\mathrm{r}=.85$, 形態類似条件 : $r=.76$, 音韻同一条件 $: r=.89$ ).

\section{考察}

本実験に抢ける課題遂行には, 背景の形態特徵 あるいは音韻特徵の処理及び標的か否かの判断が 必要である。このうち形態特徵は, 周辺視によっ て処理することができる。これに対し音韻特徵の 処理には，文字の同定を必要とする．さらに標的 か否かの判断過程は, 標的とのマッチングを行う 高次な処理過程であると考えられる。

文字の認知過程についての仮説の一つとして， 単純な形態特徵分析の後に，それを基にしたより 複雑な音韻特徵分析に進むという，パンデモニウ ム的なヒエラルキーモデルがある。この仮説によ ると, 形態処理と音韻処理とは継時的に進行する と考光られる. しかし，文字の異同判断 (Posner, $1969)$, あるいはタキストスコープを用いた文字 判断課題 (Henderson, 1972 ) 等の実験が示唆する ように, 現在では形態処理と音韻処理は, 平行し て行われるとする仮説が有力である. 序論でも述 ベたように，視覚的探索事態に扔いてもまた，背 景に対する形態処理と音韻処理が平行して行われ ていることが実験的に示されている (Henderson, 1973 ). 特に日本語かな文字は一文字一音節とい ら特徵を持っており, これらの処理が密接して進 行すると考えてよいであろら。

探索所要時間は, 形態類似条件のみならず音韻 同一条件でもまた，コントロール条件より延長し た.この結果は, 形態特徵分析によって遂行可能 な課題であっても，リスト中の背景文字に対する 音韻的処理がなされていたことを示して扮り， Henderson (1973)の結果と一致する。さらに, 形 態類似条件々音韻同一条件を比較すると, 形態類
似条件の方が探索所要時間が延長した。この点も またHenderson (1973)の結果に一致している。こ れら 3 条件間でみられた探索時間差が，どのよう な処理内容の違いによって生じたものであるかを 明らかにするために, 眼球運動の分析を通して検 討を試みた。

まず，停留時間については，コントロール条件 と他の 2 条件との間で差が生じた。コントロール 条件と他の 2 条件との違いは，妨害文字を含むか 含まないかといら点にある. 即ち, 形態類似条件 及び音韻同一条件では，妨害文字が存在すること によって標的か否かの判断が紛らわしくなったた めに, コントロール条件に比べて停留時間が延長 したと考觉られる。このような判断過程は意味同 定を必要とする認知レベルでの高次な処理であ る. Printz and Nattkemper ( 1986 )は，意味同定 処理の指標として, 列あたりの探索時間を用いて いる。しかし，本実験で用いた停留時間もまた制 御探索を測定することができる指標であると考え られる．停留時間を用いることによって，より直 接的に背景に対する意味同定処理過程を測定する ことができるであろう。

探索時に扔けるサッケイドは主に，周辺視で得 た情報に依存している. 可視範囲内に標的文字と 形態的に類似した文字がある場合，その文字が自 動的に捕らえられ誤ったサッケイドが生じる．本 実験で用いたサッケイド回数が周辺視による感覚 特徵処理を反映するものであるならば，サッケイ ド回数は形態類似条件のみで増加すると考えられ る。しかし, 結果から, 音韻同一条件でもまた回 数が増加していた。 即ち, 音韻同一文字もまた周 辺視によって捕えられていたことになり, サッケ イド回数が感覚特徵処理だけでなく音韻処理にも 影響を受けることが示されている.Printz and Nattkemper (1986)は，感覚特徵の指標として垂 直検出距離を用いている。乙かし, 垂直検出距離 は標的文字が存在する場合にしか用いることがで きない，本実験で用いたサッケイド回数は，標的 
が存在しなくても，また検出反応を必要としない 場合でも用いることができるといら利点がある。 今後このサッケイドを, 方向もしくはその距離と いら観点からより詳細に検討することによって， 感覚特徵処理に関する指標として用いることが期 待される。

最後に, 形態類似条件と音韻同一条件間で示さ れた探索所要時間の差は, どの様な要因により生 じたものであったかといら問題が残る。本実験に おいて, 探索所要時間はサッケイド回数と高い相 関があることが示された (Fig. 6).このことから， 形態類似条件之音韻同一条件のサッケイド回数の 間に差があることが予想されたが，統計的には有 意でなかった。この結果から，条件による効果 が，サッケイド回数あるいは停留時間以外の要因 を媒介して探索所要時間に影響している可能性も 考えられる。

本実験の結果を要約すると次の通りである．形 態類似条件では，周辺視によって標的に類似した 文字を誤って捕らえるためにサッケイド回数が増 加した．音韻同一条件でもまた可視範囲内の音韻 同一文字に対してサッケイドを起こすが，その回 数は形態類似条件よりも少なかった。一方, 一旦 サッケイドによって中心視に置かれた文字は，標 的か標的でないかの判断が必要である。この段階 に颃いて，音韻的及び形態的妨害文字は共に，標 的との異同判断を困難にし，コントロール条件よ りも停留時間が延長することになる。しかし，形 態的妨害, 音韻的妨害間ではその処理時間に差は ないため，両条件間での停留時間には差は示され なかった。

このように，文字リスト中の背景文字の処理 は, 周辺視での把握可能性, 及び標的か否かの判
断の困難度とい52つの要因が影響することが， 眼球運動の結果から示唆された。今後, サッケイ ド方向，距離などをさらに分析することによっ て，探索事態に拈ける処理内容を明らかしていく ことができると思われる。

\section{引用文献}

Henderson, L. 1972 Spatial and verbal codes and the capacity of STM. Quart. J. Exp. Psychol., 24, 485-495.

Henderson, L. 1973 Effects of letter-names on visual search. Cogn. Psychol., 5, 90-96.

Neisser, U. 1963 Decision time without reaction time : Experiments in visual scanning. Amer. J. Psychol., 76, 376-385.

Posner, M. I. 1969 Abstraction and the process of recognition. In C. H. Bower, \& J. T. Spence (Eds.), Psychology of Learning and Motivation. New York: Academic Press.

Printz, W. 1986 Continuous selection. Psychol. Res., 48, 231-238.

Printz, W., \& Kehrer, L. 1982 Recording detection distances in continuous visual search. In R. Groner, \& P. Fraisse (Eds.), Cognition and Eye Movements. Berlin : Deutscher Verlag der Wissenschaften. p. $48-56$.

Printz, W., \& Nattkemper, D. 1986 Effects of secondary tasks on search performance. Psychol. Res., 48, 47-52.

Rayner, K., \& Pollatsek, A. 1981 Eye movement control during reading : Evidence for direct control. Quart. J. Exp. Psychol., 33, 351-373. 